\title{
SPEECH DELAY THERAPY FOR CHILDREN USING THE AAC METHOD
}

\author{
Natalina Purba ${ }^{1}$, Mira Kusumo Astuti ${ }^{2}$ \\ ${ }^{1}$ Universitas HKBP Nommensen Pematangsiantar \\ ${ }^{2}$ Universitas Negeri Jakarta \\ 1natalinapurba@aol.com, ${ }^{2}$ admirals_secret@yahoo.com
}

\begin{abstract}
The purpose of this study (1) The factors that cause speech delay in early childhood (2) The treatment given by Permata Diakonia and parents? (3) The impact of speech therapy performed by Permata Diakonia using the AAC (Augmentative Alternative Communication) method. Methods: This study used a case study method with one child data analysis used qualitative data analysis with Miles and Huberman methods. Results: Sensory therapy that was given every day since the child was diagnosed late speaking had a very significant impact on the child's environmental response. A good response to this environment is a sign that the child can be given speech therapy using the AAC method which is given twice a week. From this study, it can be concluded that speech therapy using the AAC method significantly improves children's speaking ability. It should be noted that the key to success in this therapy is not changing therapists. Implication: speech therapy using the AAC method has implications for new ideas that will give new ideas to new approaches to enrich speech therapy.
\end{abstract}

Keywords: AAC, sensory integration therapy, speech delay, and speech therapy

\begin{abstract}
Abstrak
Tujuan penelitian ini (1) Faktor-faktor yang menyebabkan keterlambatan bicara (speech delay) pada anak usia dini (2) Perlakukan yang diberikan oleh Permata Diakonia dan orang tua? (3) Dampak dari terapi bicara yang dilakukan oleh Permata Diakonia dengan menggunakan metode AAC (Augmentative Alternative Communication). Metode: penelitian ini menggunakan metode studi kasus dengan satu orang anak, analisis data menggunakan analisis data kualitatif metode Miles dan Huberman. Hasil: Terapi sensori yang diberikan setiap hari sejak anak didiagnosa terlambat bicara berdampak sangat signifikan terhadap respon lingkungan anak. Respon yang baik terhadap lingkungan ini sebagai pertanda anak dapat diberikan terapi wicara dengan menggunakan metode AAC yang diberikan dua kali seminggu. Dari penelitian ini dapat disimpulkan terapi wicara menggunakan metode AAC signifikan meningkatkan kemampuan berbicara anak. Perlu diperhatikan kunci sukses dalam terapi ini adalah tidak berganti-ganti terapis. Implikasi : terapi wicara dengan menggunakan metode AAC berimplikasi pada ide baru yang akan melahirkan pendekatan baru untuk memperkaya terapi wicara.
\end{abstract}

Kata Kunci: AAC, sensori integrasi, keterlambatan bicara, terapi wicara

\section{INTRODUCTION}

Communication is the right of every individual no one can take that right. It is inconceivable if humans cannot communicate with the people around them, surely the world will feel lonely. Communication is one of the most basic human needs and must be fulfil.

Since a long time ago, humans have used verbal and non-verbal communication when conveying messages to others. Communication will be very meaningful when the message that is delivered is well received by the recipient of the message, the 2-way communication is going 
well. If communication does not work properly, especially in early childhood whose language skills are still developing, there will be communication problems in children.

When a child can express what he wants, the child can be taught to communicate. When communication is hampered, the child must be given a series of interventions so that the child can communicate with other people, at least other people understand what the child is saying. UNICEF says that communication is a child's right, therefore do not take away the child's right to communicate.

To help children practice speaking, they need a method that can help children to be able to communicate. One special method for teaching children to communicate is the Picture Exchange Communication System (PECS). The use of this method allows children to quickly learn to communicate. This is evidenced by the research conducted by Suchowierska and friends, which is a method that has been specially made for individuals who have difficulty in language development. This method is evidence-based to teach how to communicate effectively and efficiently (Suchowierska et al., 2013). This is based on Skinner's thinking about behavior analysis so that children will be able to socialize with their peers.

In line with the research of Suchowierska and friends, Ganz and his friends also found PECS to be effective in improving ASD (Autism Spectrum Disorder) speaking ability (Ganz et al., 2015). Research has been carried out from year to year to determine the effectiveness of PECS, either by case studies or by meta-analysis, both of which show that PECS is effective for children with special needs, so this method is the choice in therapy for children with special needs.

But what about speech delay children, is this PECS method appropriate to be applied? Walaupu is essentially AAC (Augmentative Alternative Communication) which is designed to improve functional communication between individuals with ASD (Autism Spectrum Disorders) and other developmental disabilities who have significant communication disorders (Flores et al., 2012). This AAC is visual-based for strengthening expressive and receptive communication and other behavioral principles. Users are trained to communicate via pictures and PECS using low-cost materials that are relatively easy to manufacture so that they can be applied in schools with minimal skills.

This AAC method will be applied to children with special needs, one child who has a disability or additional functional disorder such as speech delay at Permata Diakoni using the case study method, and the formulation of the problem as follows (1) What factors what causes 
speech delay in early hildhood? (2) The treatment given by Permata Diakonia and parents? 3) Impact of the Speech Therapy Program on speech delay using AAC?

\section{METHOD}

The research approach used in this research is a qualitative approach with the strategy or method used is the case study method. A case study according to Stake is a research strategy or method in which researchers carefully investigate a program, event, activity, process, or group of individuals (Crowe, 2011). The research site was conducted at Permata Diakonia in 2019. The steps of this research consisted of 7 (seven) stages, namely: (1) Identification of cases; (2) Case selection; (3) Selecting a research phenomenon or issue; (4) Choosing the forms of data to be collected; (5) Collecting information, data and documents directly in the field using the data collection instruments prepared in the previous step; (6) Interpretation; (7) Prepare reports on the results of case studies (Creswell, 2014, Creswell, 2009).

\section{Data and Data Sources}

The data to be collected in this case study are:

1. Words, opinions, or ideas are gathered either through structured or unstructured interviews (usually in-depth interviews).

2. Notes and writings collected from notes or diaries, official letters, books.

3. Images or photos collected from photo tools (camera) and sketches.

The data sources of this research come from primary data sources and secondary data sources. Primary data sources are data obtained directly from parents, teachers, and child therapists who have difficulty communicating with others. Secondary data is data collected to complement primary data related to the problem under study. Secondary data sources include notes or diaries, official letters, books, archives, and photographs.

\section{Data Collection Techniques and Procedures}

Data collection techniques in this study were interviews, observation, documentation, and field notes. 1. Interview, conducted in a structured and unstructured manner. 2. Observation, carried out to obtain the data or information needed with regard to research problems. 3. Documentation is done by collecting and studying data from both official and unofficial documents related to the research subject, such as research results, official letters, books, archives, notes or diaries, and photos (Corbin \& Strauss, 2010, Sutton \& Austin, 2015)

\section{Data Analysis Procedure}


Data analysis in qualitative research is included in case studies carried out before entering the field, during the field, and after the data collection process. Since the data analysis model used in this study is the model of Miles and Huberman and both argue that the qualitative data analysis process is divided into two stages, namely when and after the data collection process, the data analysis procedure of this study also consists of two stages as stated by Miles and Huberman.

The data analysis procedure according to Miles and Huberman was carried out interactively and continuously until it was complete and the data was saturated. The data analysis procedure includes: (1) data reduction focusing on simplification, abstracting and transformation of crude data that emerges from written notes in the field; (2) data presentation (data display) the activity of compiling a $\mathrm{AK}$ of information, thus giving the possibility of drawing conclusions and taking action; and (3) conclusion drawing and verification of conclusions or verification carried out by researchers continuously while in the field (Onwuegbuzie \& Weinbaum, 2016). Of the three stages of the data analysis procedure, the presentation of the data took the most time and attention of the research team.

\section{Data Validity Check}

This step is important in order to ascertain whether the interpretation and research findings are accurate or the research credibility can be achieved. Checking the validity of the data in this study was carried out by triangulation (Mertens \& Hesse-Biber, 2012). Triangulation is a data validity checking technique that uses something other than the data for checking purposes or as a comparison to the data. There are three forms of triangulation, namely triangulation of sources, triangulation of techniques, and triangulation of time.

\section{RESULTS AND DISCUSSION}

\section{Results}

Based on data analysis carried out in stages starting from domain analysis, taxonomic analysis, component analysis, and theme analysis, to the research sub-focus, various findings were found, including:

\section{Factors of Speech Delay}

Analyzed medical records showed that AK had no abnormalities from the time of the womb to the birth process. However, it is necessary to pay attention to the 'ngences' phase (saliva coming out of the mouth) experienced by AK in a fairly long period of time, namely 6 years 7 months. Furthermore, the authors conducted in-depth interviews with AK's 
grandmother from her mother and father. This was intended to dig deeper into other influences that made AK late in speaking.

\section{The treatment given by Permata Diakonia and Parents}

As soon as she was diagnosed with a speech delay, the mother prepared steps to catch up with AK's speech development. These steps are often consulted by a psychologist. After consulting with psychologists at Permata Diakonia, it was agreed that the first therapy given was sensory integration. It aims to stimulate children's ability to process stimuli through the five senses (Perkins, 2011), this therapy aims to improve children's language skills and learning abilities. In addition, sensory integration therapy also aims to see children's responses to the surrounding environment (Tung et al., 2012). After AK was able to give an appropriate response to the response given, then $\mathrm{AK}$ was given speech therapy.

This is supported by research conducted by Falkus et al, that the positive effect of interacting parents with children with speech delays will accelerate the language development of their children (Falkus et al., 2016) that the bond between parents and children will certainly be stronger. due to intense interactions.

\section{Impact of a Speech Therapy Program conducted using the AAC method}

The place for learning and therapy is the Permata Diakonia and parents also call private tutors to their homes. Therapeutic activities in two areas are Permata Diakonia and private at home. This is indicated by the high frequency of therapy carried out in these two places. In addition, AK's parents, along with psychologists and therapists, always discuss to formulate therapeutic activities that AK will carry out and the goals to be achieved. So with this process, parents hope that AK will be able to catch up with his language development.

Speech therapy is carried out using a PECS (Schreibman \& Stahmer, 2014). PECS training rules are designed to systematically construct one learned behavior in order to achieve more freedom of communication (Boesch et al., 2013). This proves that AK is very helpful with this PECS method. This is also supported by research conducted by Natalina Purba and her friends through the effectiveness test of the vocabulary card which is very effective in improving the speaking ability of children with special needs, in this case mentally retarded children are able to train (Purba et al., 2019).

The pictures used for AK's speech therapy program are of course very varied with very attractive pictures and colors so that $\mathrm{AK}$ does not get bored quickly when he is running the talk therapy program which lasts 90 minutes. This is supported by research conducted by Natalina Purba and friends that the thing that must be considered when choosing an image is color (Purba 
et al., 2018). These colors, shapes, sizes, positions, background images, and textures are things -things that must be considered and the main focus of choosing a vocabulary card is the color.

\section{Discussion}

\section{Factors that cause speech delay in children}

Based on the results of medical records during pregnancy to birth AK: a. From the time of pregnancy to the birth of AK, Mother had no health complaints that could lead to an emergency. So that AKh's health check has no problem, b. AK also can only chew rice at the age of 2 years.

Based on the results of interviews with AK's maternal and paternal grandmother.; a. The maternal grandmother explained that the maternal family experienced a phase of normal language development starting from the mother of AK and her siblings, nephews to grandchildren, b. Grandmother on her father's side explained that AK's father experienced a significant delay in speaking because he was only able to speak at the age of 5 years, c. The paternal grandmother also explained that currently one of the grandchildren who is now 2 years old is still unable to speak.

Based on observational records for the first two years: a. The author does not find significant obstacles in communicating within the family which is done only in Indonesian, $b$. The AK likes cognitive stimulating games such as stacking blocks and geometry. C. AK also likes outdoor activities and often visits the playground.

Based on observations of notes on language development from a cognitive aspect: a. The author looks at the 0-6 month phase, AK has been able to: AK pay attention to the activities of those around him; Sweet AK to indicate hunger, fatigue, and pain; AK likes to be carried by his parents; AK watched the person calling his name; AK likes to see the faces of those around him; AK often expresses himself by laughing or crying, $b$. The author found that at the age of 7-12 months, AK likes to stomp his feet or hands to show something; AK glanced at the objects carried by those around him; AK yelling or tugging at the clothes of those around him for attention; The AK can show dislike or anger by shouting, $\mathrm{c}$. The author found that at the age of 13-18 months, AK pointed at the object he wanted; AK can resist by shaking his head or moving away from objects that he does not like, $d$. The author found that sat the age of 19-24 months, AK had his own designation for the object he pointed at; AKs tend to use body language to communicate with those around them. 
McDevitt and Ormrod explain that speech development begins long before children are able to pronounce their first words (McDavitt \& Omrad, 1989). In addition, parents have also tried to improve AK's interaction skills by inviting AK to outdoor activities and having a fixed schedule for visiting the playground. This is related to stimulating the AK to interact in a wider environment but in a relaxed and relaxed context because it is packaged as a vacation vehicle. However, the semantic, syntactic, and articulation aspects have not developed at all in the 024 month age phase.

For vocabulary, AK, at the age of 3 to 4 years, has not been able to use two words, even he has not been able to use verbs. By the third year, a child has mastered 900 to 1000 words. At the age of 6 years, a person has been able to apply expressive speaking using a vocabulary variation of 2,600 words and has understood more than 20,000 words (Melby-Lervåg et al., 2012). With the help of processes in elementary to high school, children are able to master and understand 80,000 words. The process of mastery of vocabulary is supported by the ability of "quick mapping" which is owned by a child where this ability is used by a child to understand the meaning of a word when hearing the word spoken in the context of a conversation. Research shows that children under 3 years are able to quickly map the use of certain verbs so that they can be placed in other sentences. Many 3 to 4-year-olds are able to use two words that refer to the same object or action.

For Grammar and Syntax, AK has understood the concept of sentences but still cannot express it. The way children combine syllables into words and words that make perfect sentences, this development occurs starting from the age of 3 years. Although it is still too generalizing a language rule. At the age of 5 to 7 years, children can speak like adults (Papalia et al., 2009). They speak using longer and more complex sentences. Even though children at this age speak fluently, comprehensively and grammar correctly, there are some language points that they have not mastered such as the concept of passive sentences and conditional sentences.

Pragmatic devices are limited to short sentences and using gestures. Papalia and her friends explained that the more children learn vocabulary, grammar, and syntax, the more competent they are in pragmatics (Papalia et al., 2009). Pragmatics is linguistic knowledge about how to use language for communication. This includes understanding how to ask questions, how to tell a funny story, and how to start a conversation. With pronunciation and grammar skills, it makes it easier for others to understand what kids say. Most 3-year-olds are 
active speakers. If other people do not understand what he said, they will try to explain again what they said.

Pronunciation skills continue to develop during the elementary school phase. Children cannot master all phonemes until the age of 8 . In childhood, children have difficulty pronouncing $\mathrm{r}$ and th. Many children can master pronunciation at the age of 6 but they still have difficulty pronouncing diphthongs: such as str, sl, and dr (McDavitt \& Omrad, 1989), with diligence and discipline AK can pronounce diphthongs well even though there are still diphthongs unclear.

\section{Care provided by Permata Diakonia and Parents}

After agreeing that integrated sensory therapy would be the initial therapy given to AK. The parents tried to cooperate with Permata Diakonia. Integrated sensory therapy includes tactile, vestibular, proprioceptive, visual, auditory, olfactory, and taste aspects. AK underwent sensory integration therapy from 2 years and 26 days of age. The authors note that the program is thoroughly designed to stimulate the sensory integration of AK. Besides, to maximize the results of sensory integration therapy, AK's parents requested 5 integrated sensory therapy times a week according to the therapy record table presented in the findings. AK's parents usually make a schedule 2 times a week to invite AK to do outdoor activities. Also, AK is free to do exercises related to sensory integration therapy performed at home.

Then, speech therapy began to be given by AK at the age of 5 years 5 months at Permata Diakonia Pematangsiantar. However, integrated sensory therapy is not immediately eliminated because the frequency of therapy is given 2 times talk therapy and 2 times integrated sensory therapy each week. 9 months later, when AK was 6 years and 4 months old, his parents started to intensify speech therapy at home 6 times a week.

\section{Impact of the Speech Therapy Program provided using the AAC method}

This integrated sensory therapy became AK's footing before entering speech therapy. Focus learning, sit quietly, and process the information around them through integrated sensory therapy that is guided by a therapist and supervised by the mother and assisted by two caregivers. Furthermore, the impact of AK's speech therapy is divided into four aspects, namely semantic, syntactic, pragmatic, and articulation aspects.

Speech Therapy with the PECS method is very effective in improving his speaking skills. Although more evidence is needed for this, PECS remains the main choice in learning new vocabulary for children, this is supported by Lerna and her friends that PECS remains the main choice for children with communication disabilities (Lerna et al., 2012). The AK with 
very minimal skills at the start of therapy both syntactically, practically, articulated, and semantically, at the end of therapy using the AAC method has tremendous progress.

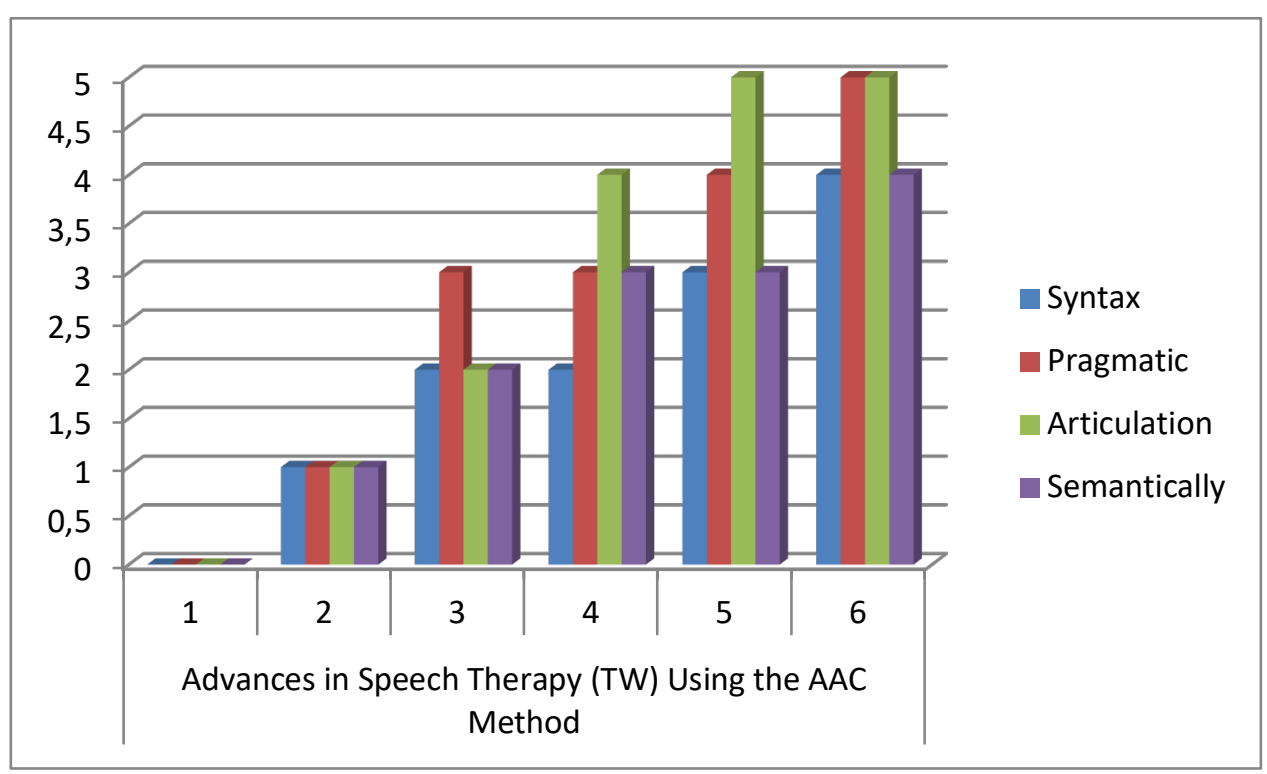

Figure 1. Advances in Speech Therapy (TW) Using the AAC Method

The graphic above shows the tremendous progress made by AK, slowly but surely AK has mastered the syntax, can place words well. Pragmatic is developing well when $\mathrm{AK}$ is hungry, AK will say "mam" (eat) meaning that AK wants to eat. Articulation had tremendous progress after AK underwent SI, almost all the words spoken were heard clearly. Semantics also makes progress when meeting a cat, $\mathrm{AK}$ will imitate his voice, meow. It is proven that SI accelerates AK's speech therapy by using the AAC method.

\section{CONCLUSION}

Children diagnosed with speech delay that was first given were Sensory Integration (SI) than speech therapy (TW). The SI and TW programs provided require collaboration with parents so that progress and maximum results are achieved. The drilling method is very effective so that children speak quickly. A therapist who does not change is one of the keys to the success of speech therapy. The AAC method is very effective in improving speaking skills. Although more evidence is needed for this, AAC remains the main choice. 


\section{ACKNOWLEDGMENTS}

Principal of Permata Diakonia Pematangsiantar School, dr. Mira Kusumo Astuti and her son.

\section{REFERENCES}

Boesch, M. C., Wendt, O., Subramanian, A., \& Hsu, N. (2013). Comparative efficacy of the picture exchange communication system (PECS) versus a speech-generating device: Effects on social-communicative skills and speech development. AAC: Augmentative and Alternative Communication, 29(3), 197-209. https://doi.org/10.3109/07434618.2013.818059

Corbin, B. J., \& Strauss, A. (2010). Comptes rendus, 36(2), 1-3.

Creswell, J. W. (2009). Research Desain. University Of Nebraska-Lincoln (3 rd). Los Angeles: Sage Publication. Inc. https://doi.org/10.1002/t1.20234

Creswell, J. W. (2014). RESEARCH DESIGN. (K. Koscielak, Ed.) (4 TH). Los Angeles: Sage Pر هنگ و رسانه هاى= نوين\&option=com_dbook\&task=readonline\&book_id=13650\&page=73\&chkhashk=ED9 C9491B4\&Itemid $=218 \&$ lang $=$ fa\&tmpl $=$ component

Crowe, et al. (2011). Methoddssss. Business Communication Quarterly. https://doi.org/10.1177/108056999305600409

Falkus, G., Tilley, C., Thomas, C., Hockey, H., Kennedy, A., Arnold, T., ... Pring, T. (2016). Assessing the effectiveness of parent-child interaction therapy with language delayed children: A clinical investigation. Child Language Teaching and Therapy, 32(1), 7-17. https://doi.org/10.1177/0265659015574918

Flores, M., Musgrove, K., Renner, S., Hinton, V., Strozier, S., Franklin, S., \& Hil, D. (2012). A comparison of communication using the apple ipad and a picture-based system. $A A C$ : Augmentative and Alternative Communication, 28(2), 74-84. https://doi.org/10.3109/07434618.2011.644579

Ganz, J. B., Hong, E. R., Gilliland, W., Morin, K., \& Svenkerud, N. (2015). Research in Autism Spectrum Disorders Comparison between visual scene displays and exchange- based communication in augmentative and alternative communication for children with ASD. Research in Autism Spectrum Disorders, 11, 27-41. https://doi.org/10.1016/j.rasd.2014.11.005

Lerna, A., Esposito, D., Conson, M., Russo, L., \& Massagli, A. (2012). Social-communicative effects of the Picture Exchange Communication System (PECS) in Autism Spectrum Disorders. International Journal of Language and Communication Disorders, 47(5), 609617. https://doi.org/10.1111/j.1460-6984.2012.00172.x

McDavitt, Teresa M., Omrad, J. E. (1989). Child Development and Education. The Journal of Negro Education, 58(2), 125. https://doi.org/10.2307/2295587

Melby-Lervåg, M., Lervåg, A., Lyster, S. A. H., Klem, M., Hagtvet, B., \& Hulme, C. (2012). Nonword-Repetition Ability Does Not Appear to Be a Causal Influence on Children's Vocabulary Development. Psychological Science, 23(10), 1092-1098. https://doi.org/10.1177/0956797612443833

Mertens, D. M., \& Hesse-Biber, S. (2012). Triangulation and Mixed Methods Research: Provocative Positions. Journal of Mixed Methods Research, 6(2), 75-79. https://doi.org/10.1177/1558689812437100 
Onwuegbuzie, A. J., \& Weinbaum, R. K. (2016). Mapping Miles and Huberman's Within-Case and Cross-Case Analysis Methods onto the Literature Review Process. Journal of Educational Issues, 2(1), 265. https://doi.org/10.5296/jei.v2i1.9217

Papalia, Diane E., Olds, Sally W., dan Feldman, R. D. (2009). A Child's World: Infancy Through Adolescence. USA: USA: McGraw-Hill International.

Perkins, S. (2011). Sensory Integration Therapy and Speech-Language Therapy, 2010-2012.

Purba, N., Handini, M. C. H., \& Yetti, E. (2018). Development of Media Vocabulary Cards to Improve the Speech Competence of Children with Intellectual Disabilities, 6 .

Purba, N., Tiar, R., Purba, L., Handini, M. C., \& Yetti, E. (2019). Efektivitas Media Kartu Kosakata Di Slb / C Arrahman Jakarta, 10(1).

Schreibman, L. E. (University of C. S. D., \& Stahmer, A. C. (University of C. S. D. (2014). A Randomized Trial Comparison of the Effects of Verbal and Pictorial Naturalistic Communication Strategies on Spoken Language for Young Children. Journal of Autism and Developmental Disorders, 44(5), 1244-1251. https://doi.org/10.1016/j.biotechadv.2011.08.021.Secreted

Suchowierska, M., Rupińska, M., \& Bondy, A. (2013). Picture Exchange Communication System ( PECS ): A Short " tutorial" for the doctors Picture Exchange Communication System ( PECS ): „, Przewodnik” dla lekarzy, (1), 85-90.

Sutton, J., \& Austin, Z. (2015). Qualitative Research: Data Collection, Analysis , and Management, 68(3), 226-231.

Tung, L. C., Lin, C. K., Hsieh, C. L., Chen, C. C., Huang, C. T., \& Wang, C. H. (2012). Sensory integration dysfunction affects efficacy of speech therapy on children with functional articulation disorders. Neuropsychiatric Disease and Treatment, 9(1), 87-92. https://doi.org/10.2147/NDT.S40499 